Advanced Energy: An International Journal (AEIJ), Vol. 5, No. 2, April 2018

\title{
FEASIBILITY STUDY OF ORKNEY'S WINDFARM DEVELOPMENT FOR SELF-SUFFICIENT FOR ENERGY IN ELECTRICITY DEMAND AND ROAD TRANSPORT SECTORS
}

\author{
Prattana Kaewpet ${ }^{1}$, Colin Bullen ${ }^{2}$ \\ ${ }^{1}$ Corresponding Author: Department of Electrical Engineering, Faculty of Engineering, \\ King Mongkut's Institute of Technology Ladkrabang, Chalongkrung 1 Rd., Ladkrabang, \\ Bangkok, Thailand, 10520. \\ ${ }^{2}$ International Center for Island Technology, School of Energy, Geoscience, Infrastructure \\ and Society, Heriot-Watt Univeristy, Old Academy, Back Road, Stromness, Orkney, \\ KW16 3AW, Scotland.
}

\begin{abstract}
In Orkney islands, a number of wind energy projects have been established due to its potential for wind energy development especially as cluster developments on hilltop and moorland. This Self-sufficient Orkney Wind Energy (SOWE) project is trying to follow this pattern of development and has designed as a simple linear development of medium-large scale wind turbines which avoids dominating the landscape, while providing diversification required for the energy security, along with strong economic benefits to the local community. The developer completed preliminary designs and landscape assessment, resulting in the detailed design and the development of 27 wind turbine project for the expectation to generated electricity of 549.2 GWh annually.
\end{abstract}

The SOWE project has been designed and selected the use of the Enercon E44 - $900 \mathrm{~kW}$ and Norex N80 $2.5 \mathrm{MW}$ wind turbines. These machines represent the maximum scale, respectively, as;

- $\quad$ the site layout and all modelling have used a 45m, and $60 \mathrm{~m}$ turbine tower height;

- $\quad$ a rotor diameter of $44 \mathrm{~m}$, and $80 \mathrm{~m}$; and

- $\quad$ The blade length is $22 \mathrm{~m}$ and $40 \mathrm{~m}$.

It has been found that the SOWE project provides a promising contribution towards the Scottish Government renewable energy production and carbon reduction targets.

\section{KEYWORDS}

feasibility study, windfarm, Orkney, road transport

\section{INTRODUCTION}

Wind energy is the transformation of kinetic energy that is obtained from the moving air. Because the amount of power and energy output substantially increase as the wind speed increases, the most cost-effective wind turbines are located in the windiest areas. Wind energy can be used for either mechanical application: mainly (water pumping) (see Figure 1) or electricity generation. Wind energy has a number of benefits which make it an ideal renewable energy, as can be described as follows:

DOI : 10.5121/aeij.2018.5201 
- Wind energy is a sustainable form of energy as it is pollution-free.

- It does not create greenhouse gases, toxic or radioactive waste.

- Any fuel is not required.

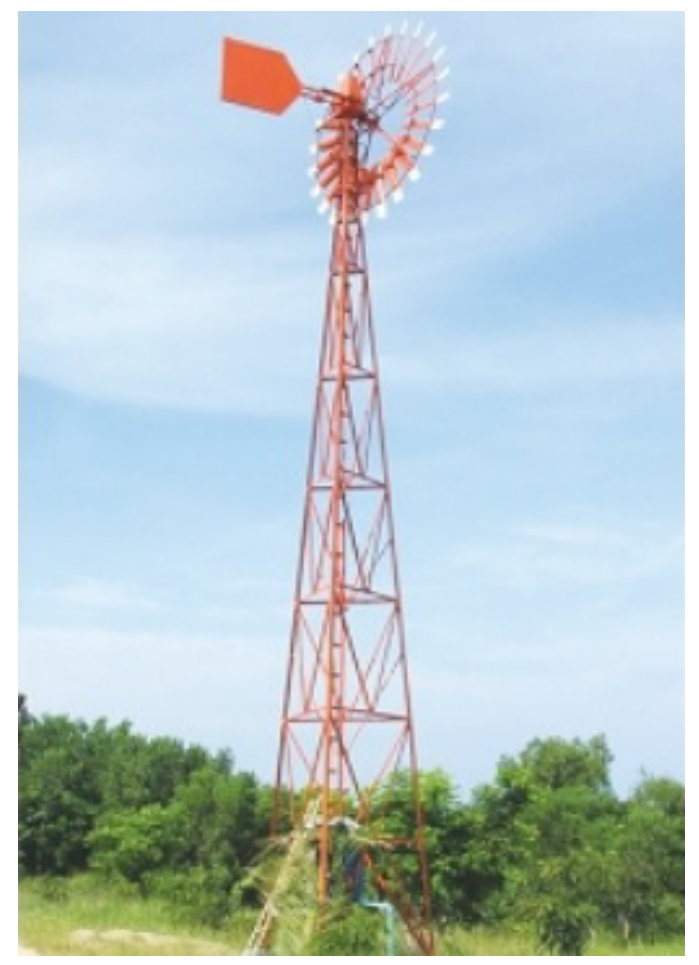

Figure 1: The component of wind turbines to pump water for agricultural purpose (DEDE (Department of Alternative Energy Development and Efficiency), 2018)

However, producing energy from wind using wind machines can cause some negative effects on environment such as on wild bird populations and the visual impact on the landscape (Office of Energy efficiency \& Renewable Energy, 2018). Wind turbines may also cause noise and aesthetic pollution (An-Najah National University, 2018).

\subsection{Electricity Transmission Lines and Wind Speed in Orkney}

A grid connection application will be expected to be accepted by Scottish and Southern Energy, and it is intended that the turbines will operate under the innovative Registered Power Zone scheme. There are $11 \mathrm{kV}$ and $33 \mathrm{kV}$ electricity transmission lines in the area. And the turbines are to be connected to the local distribution system via a switchgear. The average wind speed at the proposed locations is investigated via http://www.bwea.org/noabl/. In this project, the average wind speed applied is $9.3 \mathrm{~m} / \mathrm{s}$ or $20.7 \mathrm{mph}$ according to (Orkney Sustainable Energy Ltd, n.d.) and (Assessment, 2010). Based on manufacturer's predictions, 27 wind turbines located on 8 sites proposed will have a capacity factor around $45 \%$ and will produce $549.2 \mathrm{GWh}$ of renewable capacity per annum equivalent to the Orkney electricity requirement for both electricity and road transport sectors. Approximately, the production of 268.5 thousand tonnes of carbon dioxide per annum (Carbon Trust) can be deducted from the production of electricity from renewable resources. 


\subsection{Energy Requirement in Orkney}

The resource quantified by Aquatera shows that, in the future, Orkney possesses very significant sources of renewable energy. These sources include a number of wind turbines, in which technology Orkney has been a pioneer for many years. This is the reason the developer has been introducing the project to generate electricity from wind power to sustain the electricity production within year 2030 timeframe. There are 46 of 1 MW units that receive medium level of acceptability barriers while the current electricity consumption in Orkney is given the number of around $35 \mathrm{MW}$ at maximum (Orkney Islands Council, 2009).

Given these goals, target level of wind energy generation in Orkney can be linked to levels of both electricity and electrical energy usage for transport sector. The amount of wind energy capacity would be required to meet these equivalence goals, based on $40 \%$ efficiency level according to the report provided by OIC. The installed capacity of wind energy for electricity use equivalent would be of $50 \mathrm{MW}$. With this installed capacity required, the type of electrical infrastructure required would be Active management of existing grid (Orkney Islands Council, 2009). As the electricity use equivalence of $50 \mathrm{MW}$ does not need new grid connection (Orkney Islands Council, 2009), it is expected to be achieved in Orkney in a relatively short time scale with active management of the grid. However, there is additional energy required to meet the total road transport by establishing a 75:25 mix of electric and hydrogen vehicles and supporting infrastructures to be considered. Therefore, the new $200 \mathrm{MW}$ grid connection is required.

To develop wind farms for electricity production in Orkney (see an example of wind farm in Orkney in Figure 2), some necessary documents are studied. Based on Scottish National Heritage $(\mathrm{SNH})$ guidance for strategic planning of wind farms ("Landscape Assessment for Potential Strategic Wind Energy Development in Orkney," n.d.), it is recommended that the landscape capacity for wind energy should be assessed on the basis that a degree of change to landscape character should be accepted. In general, landscape and visual resources should not be affected, and some of the more sensitive landscapes should be protected from wind energy development ("Landscape Assessment for Potential Strategic Wind Energy Development in Orkney," n.d.).

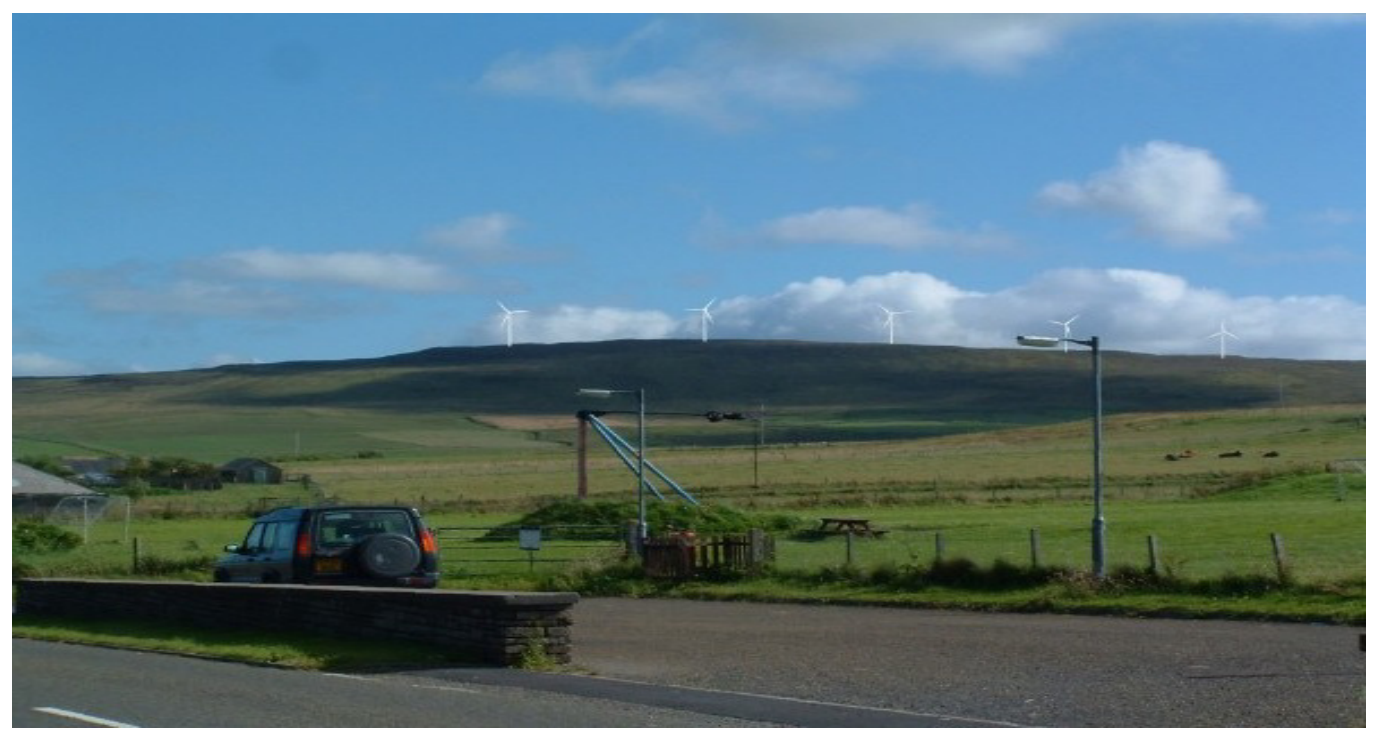

Figure 2: Hammars Hill Wind Farm viewed from Evie School (Orkney Sustainable Energy Ltd., 2017) 


\section{WIND FARM DEVELOPMENT}

The Scottish Ministers have set a target of generating $40 \%$ (since quantified s $6 \mathrm{GW}$ ) of Scotland's electricity from renewable source by 2020 and confirmed that this target should not be regarded as a cap. It is stated that the importance of using clean and sustainable energy from renewable sources will continue to increase a s a result of global goals to tackle climate change and the requirement to ensure and diverse energy supplies. As a part of Scotland, Orkney has been supported by the Scottish Ministers regarding the full range of renewable generation technologies to realise its considerable wind energy potential. Accordingly, this project will provide electricity from renewable source, wind energy to support Orkney's electricity demands (Series, n.d.).

\subsection{Scale of Wind farms}

Orkney is a remote rural island community, with no gas network, it has over recent decades had a high dependency on imported oil and coal as its main sources of energy. Orkney suffers high rates of fuel poverty due to the cool and windy climate as well as the higher costs of fuel. The costs of fuel in Orkney are higher than in other parts of the UK owning to the transportation costs involved in delivering. Because of those factors affecting Orkney's community well-being, a cost-effective way of harvesting the energy needed from renewable energy is attractive. However, due to the limitation of the grid capacity, the amount of renewable energy that Orkney can accommodate will require further upgrade of the grid as mentioned previously (in 1.1). This section gives an overview of the energy usage in Orkney. Electricity can be imported /exported to and from Orkney via two 33kV (20 MVA) submarine cables. Renewables such as wind are now the predominant potential source of electricity in Orkney (ORKNEY.COM, n.d.).

Energy use in Orkney can be categorised into three main energy uses (Aquatera Ltd, 2014) comprising Buildings and Utilities, Transport, and Residual fuel use, which encompasses all other terrestrial energy. In this windfarm development project, we are interested in the supplying annual energy requirements which include (1) electricity consumption and (2) energy requirement in road transport sector by considering their variability. Orkney's electricity consumption is equivalent to around $35 \mathrm{MW}$ at maximum. The levels of potential wind energy is very substantial, which is totally around $256 \mathrm{MW}$ installed capacity with medium and low acceptability from the community, respectively (Orkney Islands Council, 2009)]. To cover the equivalent electricity needed in road transport sector which is around $109 \mathrm{GWh}$ (Aquatera Ltd, 2014), the calculation for installed capacity in addition to the maximum electricity need from the electricity sector (35 MW), the load factor of wind energy is required. Plant load factor is the average hourly quantity of electricity supplied during the year, expressed as a percentage of the average output capability at the beginning and the end of year (Department for Business, 2016). Alternatively, it can be called as annual load factor which is the load factor of generating station over a period of a year of approximately 8,760 hours (Science Dictionary, 2017).

Onshore wind speeds in 2015 in the UK were the highest in the last fifteen years. This resulted in the highest onshore wind load factor at 29.4 per cent, and an increase of 3.0 percentage points on 2014, reflecting the higher wind speeds and technological advances in newer sites. (Department for Business, 2016). But in Orkney, L.F. is assessed to be as high as 0.45 (Assessment, 2010). Assuming the onshore wind load factor at 45\% (Assessment, 2010),

Load factor (L.F. ) $\%=\left(\frac{\text { the total number of } \mathrm{kWh} \text { supplied }}{\text { the total number of } \mathrm{kWh} \text { at its maximum continuous rating }}\right) \times 100 \%$ 
The substitute the number,

$$
\begin{aligned}
& \qquad 45=\left(\frac{109 \times 10^{6} \mathrm{kWh}}{\text { the total number of } \mathrm{kWh} \text { at its maximum continuous rating }}\right) \times 100 \% \\
& \text { the total number of kWh at its maximum continuous rating }=\left(\frac{109 \times 10^{6} \mathrm{kWh}}{45}\right) \times 100 \% \\
& \qquad=242 \times 10^{6} \mathrm{kWh}
\end{aligned}
$$

This results in the need of the installed capacity of wind farm for additional equivalent electricity for road transport of 27.7 MW. To sum up, the island's equivalent annual electricity requirements in two key sectors by 2030 - electricity demand and road transport: Energy required from wind farms $=35 \mathrm{MW}+27.7 \mathrm{MW}=62.7 \mathrm{MW}$. So, in order to provide the energy by the construction of sufficient wind farms and appropriate infrastructures, the scale of wind farm suggested would be around $62.7 \mathrm{MW}$.

\subsection{Landscape assessment}

Areas with Greatest Capacity for Wind Energy Development in Orkney identified include ("Landscape Assessment for Potential Strategic Wind Energy Development in Orkney," n.d.):

- Moorland Hill (ORK 20)

- Low Moorland (ORK 17)

- Low Island Pastures (ORK 14)

- Undulating Island Pastures (ORK 5)

Six areas in Orkney considered the highest underlying capacity for wind energy development which has been taking into consideration based on a combination of one or more factors including suitable larger scale simple landforms, landscape patterns, existing development/ land use affecting character, lower visual sensitivity and lower landscape value ("Landscape Assessment for Potential Strategic Wind Energy Development in Orkney," n.d.) are:

- Brough Ness, South Ronaldsay;

- Flotta, Fara and the landscape around Lyness to the south west of Scapa Flow;

- The south facing slopes of the Moorland Hills of West Mainland overlooking Scapa Flow;

- The northern Moorland Hills of East Mainland;

- Rothiesholm on Stronsay; and

- Spur Ness, southern Sanday. (6a): Undulating Island Pastures

According to the study of strategic wind energy development in Orkney: it can be concluded that:

- The greatest opportunities of strategic wind energy development in Orkney arise on Stronsay, south west Scapa Flow and Sanday, with developments of turbines up to $150 \mathrm{~m}$ in height potentially acceptable on Stronsay and Sanday.

- There is the potential for larger scale strategic developments on the Moorland Hills of north Mainland.

Due to the scale of recommended wind farms $(62.7 \mathrm{MW})$, this project only considers wind turbines of $50 \mathrm{~m}$ or greater in terms of their potential to generate electricity in the areas for wind farm development and their contribution to cumulative issues. In general, turbines with the dimension of smaller than $50 \mathrm{~m}$ in height have limited landscape and visual effects. 
Accordingly, the wind farm developments in each area are recommended in this feasibility study as follows:

- A single turbine (50-80m) at Low Island Pastures, Golta $=1$ turbine of

- A single turbine (50-80m) at West Flotta Low Moorland =1 turbine of

- A small array (x3 of 50-80m) at Hoy Moorland Hills, Lyness $=3$ turbines of

- A small array (x3 of 50-80m) at Brough Ness, South Ronaldsay $=3$ turbines of

- A small array (x3 of 50-80m) at South Mainland Moorland Hills = 3 turbines of

- A small windfarm (x6 of 50-80m) at North Mainland Moorland Hills (Burgar Hill) $=6$ turbines of

- A small windfarm (x5 of $125 \mathrm{~m}$ ) at Rothiesholm, Stronsay $=5$ turbines of and

- A small windfarm (x5 of 125m) at Sanday (Loth, Spur Ness) $=5$ turbines of

\subsection{Project description}

The average wind speed in different parts of Orkney can be investigated via http://www.bwea.org/noabl/. In this project, the average wind speed applied is $9.3 \mathrm{~m} / \mathrm{s}$ or 20.7 mph according to (Orkney Sustainable Energy Ltd, n.d.) and (Assessment, 2010). Based on manufacturer's predictions, the wind turbines located on these sites will have a capacity factor of around $45 \%$. The project aims to produce around $549.2 \mathrm{GWh}$ of renewable electricity per annum. Electricity produced from renewable resources avoids the emission of pollution, and the production of around 549.2 GWh of wind electricity is projected to avoid the production of around 268.5 thousand tonnes of carbon dioxide per annum (Orkney Sustainable Energy Ltd, n.d.).

\subsection{Determining wind turbine sizes}

A range of alternative wind turbine models has been considered for the proposed locations in this project. It is intended that the project should attempt to maximise generation within the identified constraints, with ecological and visual impact, noise impact, transportation and grid capacity. It was found that as the equivalent electricity needed for Orkney is around 62.7 MW, 24 wind turbines of $2.5 \mathrm{MW}$ and 3 wind turbines of $900 \mathrm{~kW}$ have been selected.

\section{TranSPORT MiX}

\subsection{Low carbon vehicle technologies}

Only the road transport sector energy usage is applied for the calculation of the future implementation of electric vehicles and fuel cell vehicles that will be required up to year 2030 . Using the data from the feasibility study of the possible levels of EVs adoption in Orkney, in moderate scenario (Lane, Tyne, \& Johnstone, 2015), based on an analysis of Orkney's population, vehicle ownership trends, and EVs growth projections from previous studies, in combination with the amount of energy produced for each sectors in road transport sector to estimate the numbers of EVs that could be adopted in Orkney by 2030. It can be recalculated from the number of EVs and the energy generated in MWh that for 1 Electric Vehicle will require around $2.8 \mathrm{MWh}$ per annum (2,549 EVs will generate 7,136 MWh). Therefore, as the energy consumption of EVs is 2.8 times less than that of fossil fuel cars, the total numbers of EVs are 9,674. The details of each type of EVs for different road transport sector are displayed in Tables 3.1- 3.3. The total wind capacity remaining from the use of EVs for road transport sector will be 
around 6MW. In this case, it could be recommended that for the developer to either reduce the wind capacity or increase the number of EVs. Alternatively, the remaining capacity can be used to produce hydrogen as a fuel for fuel cell vehicles.

Table 1: Wind energy required and produced in each sectors of road transport sector in Orkney at the load factor (L.F.) at 0.45

\begin{tabular}{|l|c|c|c|c|c|}
\hline Sector & $\begin{array}{c}\text { Total RE } \\
\text { capacity } \\
\text { (MW) }\end{array}$ & L.F.* & $\begin{array}{c}\text { Energy } \\
\text { produced per } \\
\text { annum (kWh) }\end{array}$ & $\begin{array}{c}\text { Energy required } \\
\text { for EVs (kWh) }\end{array}$ & $\begin{array}{c}\text { Number } \\
\text { of EVs }\end{array}$ \\
\hline Domestic & 11.64 & 0.45 & $45,884,880$ & $16,387,457$ & 5853 \\
\hline $\begin{array}{l}\text { Commercial \& } \\
\text { Industrial }\end{array}$ & 7.44 & 0.45 & $29,328,480$ & $10,474,457$ & 3741 \\
\hline $\begin{array}{l}\text { Public } \\
\text { Administration }\end{array}$ & 1.72 & 0.45 & $6,780,240$ & $2,421,514$ & 81 \\
\hline total & 20.8 & \multicolumn{5}{|r}{} & 9674 \\
\cline { 1 - 5 }
\end{tabular}

* (Aquatera Ltd, 2014)

Table 2: Numbers of FCVs required to fulfil the need for road transport sector in addition to EVs

\begin{tabular}{|l|c|c|c|c|}
\hline Sector & $\begin{array}{c}\text { Total RE capacity } \\
\text { (MW) }\end{array}$ & L.F. & $\begin{array}{c}\text { Energy produced per annum } \\
\text { (MWh) }\end{array}$ & $\begin{array}{c}\text { Number of } \\
\text { FCVs }\end{array}$ \\
\hline FCVs & 6.9 & 0.45 & 27298 & 5223 \\
\hline
\end{tabular}

To summarise, the numbers of EVs and FCVs that will be required for road transport sectors in Orkney for all application sectors are equivalent to 9,674 EVs and 5,223 FCVs.

Table 3: Conclusion of the number of EVs and FCVs and their energy consumption

\begin{tabular}{|l|c|c|c|c|}
\hline Vehicle Types & $\begin{array}{c}\text { Numbers of } \\
\text { Vehicles }\end{array}$ & $\begin{array}{c}\text { Energy consumed } \\
\text { (MWh) }\end{array}$ & $\begin{array}{c}\text { Energy } \\
\text { remaining } \\
\text { (MWh) }\end{array}$ & $\begin{array}{c}\text { RE Capacity } \\
\text { remained } \\
\text { (MW) }\end{array}$ \\
\hline EVs & 9674 & $29283.4^{*}$ & 52710.17 & 6 \\
\hline FCVs & 5223 & $9749.4^{* *}$ & 17548.9 & 2 \\
\hline Total & 14897 & 39032.8 & 70259.1 & 8 \\
\hline
\end{tabular}

* Assumed that Electric Vehicles is 2.8 times higher efficient than Fossil Fuel Vehicles (Lane et al., 2015)

** Assumed that FCVs is 1.5 times higher efficient than Electric Vehicles (Blamire, 2015)

\subsection{Infrastructure provision}

A key focus in the promotion of electric vehicles is the provision of recharging infrastructure. Easy access and availability to this infrastructure can influence the convenience and confidence associated with using the EVs (Lane et al., 2015). The majority of travel in Orkney is short journeys hence an ideal county to promote and encourage the use of EVs and FCVs due to their shorter range than comparable petrol/diesel vehicles at present. Existing electric charge points in Orkney are located at; Kirkwall: East Kirk Car Park, St Rognvald's House, and Great Western 
Road Car Park; St Margaret's Hope: Braeburn Court Care Home; Dounby: Dounby Primary School Car Park; and Stormness: Old Academy Business Car Park.

In the future, it is envisaged that a number of charge points will be installed specifically for the use of commercial vehicles and the remaining units will be placed in accessible locations for public use. The Council as the Planning Authority will support the inclusion of charge points and other associated infrastructure for larger developments such as hospitals, schools, leisure facilities and new housing developments where practicable (Engineering, 2012).

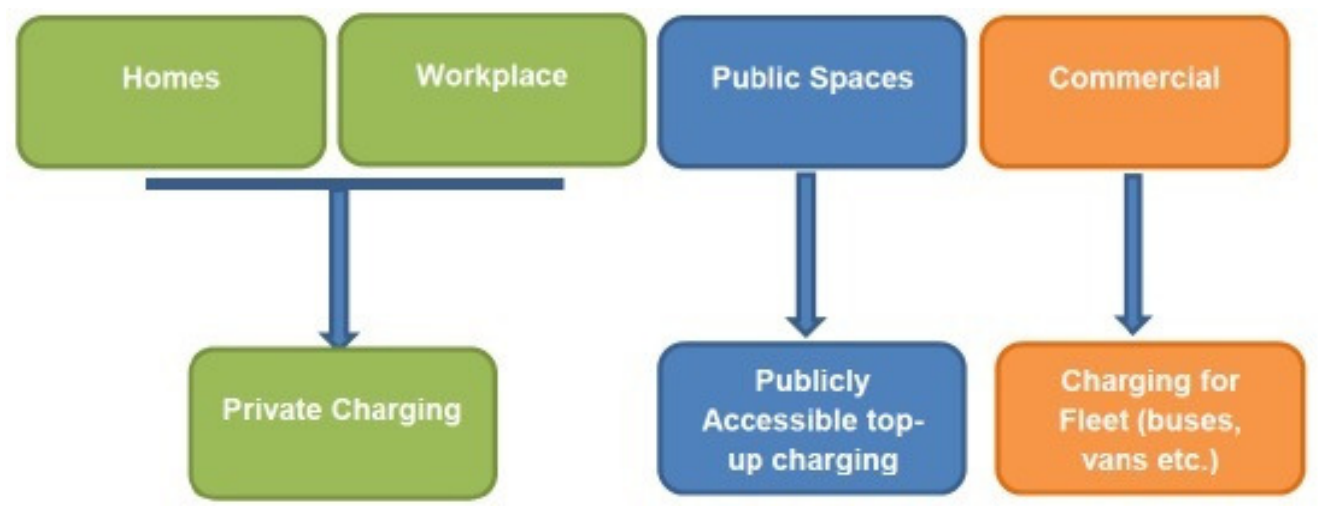

Figure 3: Likely split of charging points in Orkney (Engineering, 2012)

Overnight recharging at home should be seen as the most convenient and cost effective method to charge an electric vehicle. Future provision of public charge points may, depend on the potential to realise sufficient revenue from this infrastructure. Due to limitations and constraints on using charging points or limit of the duration of parking and recharging in some locations, it is therefore, envisaged that the majority of recharging will be completed at homes and to a lesser extent workplace areas. The commercial element should be charge points which are especially for commercial business use either by the local authority or private businesses, as shown in Figure 3.

Slow and Fast charge points are more suitable for workplace locations where the EVs can be left to charge for a prolonged period of time. EVs for commercial use may require Non-rapid charge points, in which vehicles are only used at specific times. Rapid charge points provide around $80 \%$ charge in 30 minutes while fast charge points take 3-4 hours to fully charge a battery (see more details in Figure 4). Rapid charge points are more expensive than fast or slow charge points, however, it is recommended for key locations of Stromness and Kirkwall in the first instance such as harbour areas, Kirkwall Airport, key tourist sites, recreational and/or shopping areas. The numbers of rapid charge points that can be extended will be subjected to external funding and suitable infrastructure.

Figure 4: Charge Point Types (Engineering, 2012)

\begin{tabular}{|l|l|}
\hline Charge Point Types Available in the UK. & Time to Charge. \\
\hline 'Slow' points 3kW (13A) supply. & $6-8$ hour charge time. \\
\hline $\begin{array}{l}\text { 'Fast' points single or three phase 7-22 kW (16-22A } \\
\text { supply). }\end{array}$ & $3-4$ hour charge time. \\
\hline $\begin{array}{l}\text { 'Rapid' points provide } 40 \mathrm{~kW}+\mathrm{AC} \text { or } 50 \mathrm{~kW}=\mathrm{DC} \\
\text { supply. }\end{array}$ & $80 \%$ charge in 30 minutes. \\
\hline
\end{tabular}




\subsection{Infrastructure requirements}

Orkney comprises a total area of 990 sq.km. Terrain on the islands is mainly low lying with some hilly areas and cliffs around the coastal regions. Map of Orkney and their relation to mainland Scotland is present in Figure 4.6. There are two charging networks that operate across the Islands: Charge Your Car (CYC) which also includes Charge Place Scotland (CPS), and Zero Net. Details such as charge point locations, charging network, charger type, and number of available connectors are summarised elsewhere (Lane et al., 2015)

Nevertheless, to expand infrastructure for future increasing use of EVs, factors such as the types of chargers to be installed, and their advantages and disadvantages need to be considered. For example, Fast chargers can meet a balance between the lower cost of slow chargers and the convenience of rapid chargers but they still require a minimum of 3 hours to fully charge and thus ill require longer parking stay. An additional charging plug and socket configuration of rapid charging make it more complicated than fast charging. Where Type 1 and Type 2 configurations cover both slow and fast charging, either CHAdeMO or the CCS configuration are required for rapid DC charging. Nonetheless, rapid charging still offers a significant advantage in terms of shorter charging times and is much more suitable for top-up charging to extend journeys,

\subsection{Fuel cell vehicle system}

Although EVs are more technological mature, FCVs are expected to be one of the most promising technologies for road-transport sectors. To establish the future infrastructure of FCVs filling station system (see example of wind to hydrogen facility in Figure 5), some key components have to be studied further as the safety and operational issues are still considerably important. Therefore, it is necessary to consider FCV system components as presented below:

- Fuel Cell Stack: the multicell stack uses hydrogen and oxygen to generate electrical energy. The number of cells can be varied to provide the desired output;

- Hydrogen gas storage: the hydrogen storage canisters serve as a vehicle gas tank and are being fuelled using the hydrogen produced by the hydrogen filling station. The water absorber is needed to prevent the fuel cell from being flooded with distilled water;

- Fan: the fan help improve the flow of oxygen into the fuel cell stack assisting to regulate or boost its performance;

- Hydrogen Filling Station: the $\mathrm{H}_{2}$ station comprises a number of double-membrane electrolysers that utilise electricity from wind energy to decompose water into oxygen and hydrogen. The hydrogen generated is stored inside the hydrogen canisters and will be used as a fuel for FCVs;

- Energy Management Centre: this central control unit will allow the system navigation. The navigation could help regulating the vehicle velocity, the electrolyser, as well as data measurement and acquisition in the initial stages of the infrastructure development. 


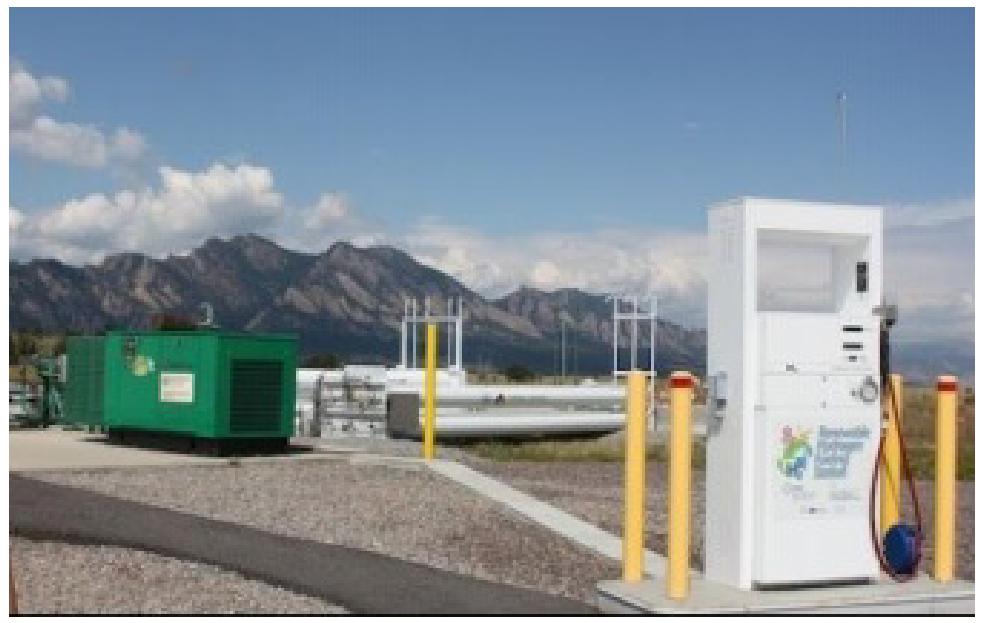

Figure 5: Wind-to-hydrogen facility at NREL (Gasteiger \& Markovic, 2003)

\section{CONCLusion}

This work has resulted in the detailed design and the development of 27 wind turbine project for the expectation to generated electricity of $549.2 \mathrm{GWh}$ annually. The SOWE project has selected the use of the Enercon E44 - $900 \mathrm{~kW}$ and Norex N80 - 2.5 MW wind turbines. A grid connection application will be expected to be accepted by Scottish and Southern Energy, and it is intended that the turbines will operate under the innovative Registered Power Zone scheme. There are 11 $\mathrm{kV}$ and $33 \mathrm{kV}$ electricity transmission lines in the area, and the turbines are to be connected to the local distribution system via a switchgear. The average wind speed at the proposed locations is $9.3 \mathrm{~m} / \mathrm{s}$. Based on manufacturer's predictions, 27 wind turbines located on 8 sites proposed will have a capacity factor around $45 \%$ and will produce $549.2 \mathrm{GWh}$ of renewable capacity per annum equivalent to the Orkney electricity requirement for both electricity and road transport sectors. Approximately, the production of 268.5 thousand tonnes of carbon dioxide per annum (Carbon Trust) can be deducted from the production of electricity from renewable resources. The total number of both EVs (75\% of energy required) and FCVs (25\% of energy required) combined that are predicted in this work for Orkney Island road users are 14,897 units which can be divided as for EVs of 9,674 and 5,223 units, respectively.

\section{ACKNOWLEDGEMENT}

I sincerely thank to Colin Bullen, a lecturer at Heriot-watt University Orkney campus, UK, for his encouragement and suggestions. This report would not have been possible without continuous moral and technical support from the Ministry of Energy, Thailand, and financial support from the Chevening, UK.

\section{REFERENCES}

[1] An-Najah National University. (2018). Adv and Challenges of wind energy.pdf.

[2] Aquatera Ltd. (2014). Orkney-wide energy audit 2014: Executive Summary. Orkney Renewable Energy

[3] Forum, (December). Retrieved from http://www.oref.co.uk/resources/orkney-energy-audit/ 
[4] Assessment, V. I. (2010). Berriedale Wind Energy Project, (December).

[5] Blamire, J. (2015). Energy Storage - The Basics.

[6] DEDE (Department of Alternative Energy Development and Efficiency). (2018). Horizontal axis wind turbine technology for water pumping in Thailand. Retrieved March 3, 2018, from http://weben.dede.go.th/webmax/content/horizontal-axis-wind-turbine-technology-water-pumpingthailand

[7] Department for Business, E. \& I. S. (2016). Digest of UK Energy Statistics (DUKES) 2016: Chapter 5, (2016), 115-155. https://doi.org/10.1007/978-1-61779-927-3 Engineering, E. (2012). Electric Vehicle Charging Infrastructure, 1-44.

[8] Gasteiger, H., \& Markovic, N. M. (2003). Fuel Cells and Wind, 40-51.

[9] Landscape Assessment for Potential Strategic Wind Energy Development in Orkney. (n.d.).

[10] Lane, B., Tyne, N., \& Johnstone, I. (2015). feasibility study orkney' s electric fu ture Adam Suleiman, (July).

[11] Office of Energy efficiency \& Renewable Energy. (2018). Application of wind energy: 1Mechanical application: mainly ( water pumping ) Multi-blade windmill used for water pumping shown below : 2-

[12] Electricity generation :Wind turbine types : 1- Vertical axis wind turbine (i . e . Darius wind turbine ).

[13] ORKNEY.COM.(n.d.).Energy of Orkney Retrieved http://www.orkney.com/invest/sectors/energy

[14] Orkney Islands Council. (2009). A Sustainable Energy Strategy for Orkney, (December).

[15] Orkney Sustainable Energy Ltd. (n.d.). Hammars Hill Wind Energy Project Technical Description and Environmental Studies.

[16] Orkney Sustainable Energy Ltd. (2017). Hammars Hill Energy. Retrieved March 3, 2018, from http://www.orkneywind.co.uk/hammars-hill-energy.html Science Dictionary. (2017). What is ANNUAL LOAD FACTOR? definition of ANNUAL LOAD

[17] FACTOR(Science Dictionary).Retrieved March 8, 2017, from http://thesciencedictionary.org/annualload-factor/ Series, P. (n.d.). Spp. 